Download

UDC 911.3

https://doi.org/1

$\underline{0.17721 / 2308-135 X .2020 .57 .65-74}$

Oliynyk Yaroslav Bogdanovich,

Taras Shevchenko National University of Kyiv, Kyiv, Ukraine,

e-mail: 521ya.ol.53@ukr.net

Doctor of Economics, Professor

Nych Tetyana Vasylivna,

Candidate of Geographical Sciences Taras Shevchenko National University of Kyiv, Kyiv, Ukraine,

e-mail: tatyana2510@ukr.net

Yavorska Karina Vitaliyivna 
Taras Shevchenko National University of Kyiv, Kyiv, Ukraine,

e-mail: yavorskaya@ukr.net

\section{EDUCATIONAL COMPLEX OF MYKOLAIV REGION: CURRENT STATE AND PROSPECTS OF DEVELOPMENT}

The purpose of research - revealing of features of development of an educational complex of the Mykolaiv area and the substantiation of the main directions of its perspective development.

The research methodology includes a system of methods: monographic, systematic approach, abstraction, mathematical, statistical, structural-functional, cartographic.

Research results. The essence of the educational complex of the region is revealed, its structure, meaning and functions are revealed. Factors of formation of an educational complex of the Mykolaiv area are revealed. Features of development and location of educational institutions are shown. Education by degree is characterized. Identified features of education levels: preschool, general, professional, fundamental professional. The estimation of the territorial organization of an educational complex of the Mykolaiv area is given. Perspective directions of further development of the educational complex of the Mykolaiv area are substantiated.

The scientific novelty of the work is the disclosure of the mechanism of formation of the educational complex of the region, the problems of its development and the directions of improvement of the territorial organization.

The practical significance of the work is that the article develops measures for further development of all components of the educational complex

Key words: educational complex, establishments of preschool education, establishments of 
general secondary education, establishments of higher education, Mykolaiv region.

References:

1. Atlas of administrative-territorial organization of Ukraine [Electronic resource]. - Mode of access:

https://www.minregion.gov.ua/wp-content/uploads/2020/10/atlas_novogo_atu_2020.pdf.

2. Analytical and descriptive part "Strategy of development of the Nikolaev area for the period till 2027" [Electronic resource]. - Mode of access:

https://economy-mk.gov.ua/index.php/ua/component/content/article/115-napriamky-diialnosti/re hionalnyi-rozvytok/sotsialno-ekonomichnyi-rozvytok/stratehichne-planuvannia/187-stratehichneplanuvannia? ltemid=437.

3. Execution of the program of development of education of the Nikolaev area in 2018 [Electronic resource]. - Mode of access:

https://www.mk-oblrada.gov.ua/news.php?news=1146\&group=32

4. Admission campaign in 2020 in institutions of professional (vocational and technical) education of Mykolayiv region [Electronic resource]. - Mode of access:

http://oblosvita.mk.gov.ua/ua/publiccouncil/1539866233. 
5. Demographic and social statistics / Education [Electronic resource]. Access mode: http://www.mk.ukrstat.gov.ua/stat_inf/oblast/osvita/osvita.htm

6. DON of the Nikolaev regional state administration [Electronic resource]. - Mode of access: https://mk.isuo.org/authorities/view/id/188.

7. Boarding schools [Electronic resource]. - Mode of access: http://oblosvita.mk.gov.ua/ua/1539112281.

8. Ilyev O. M. Territorial organization of the educational complex of the Volyn region: dissertation. geogr. Sciences: 11.00.02 - "Economic and social geography" / O. M.I liev. - Kyiv. [In Ukrainian].

9. Kaleniuk I. Education in the market environment and noneconomic values / I. Kalenyuk // Economy of Ukraine. - 2003. - No. 7 [In Ukrainian]. 
10. Komarova O .A. Formation of educational potential of society: methodology, methodology, practice: dis .... Doctor of Economic Sciences: 08.00 .03 / O.A.Komarova. - Kyiv. 2009 [In Ukrainian].

11. Melnichenko T. Yu. Educational complex of Ukraine: the current state and directions of improvement of the territorial organization: author's abstract. Dis ... Cand. geogr. Sciences: 11.00.02 / T. Yu. Melnichenko; NAS of Ukraine. Institute of Geography. - Kyiv., 2005 [In Ukrainian].

12. Network of establishments of professional (vocational and technical) education of the Nikolaev area [Electronic resource]. - Mode of access:

http://oblosvita.mk.gov.ua/ua/publiccouncil/1539114453.

13. Network of preschool institutions of the Nikolaev area [Electronic resource]. - Mode of access: http://oblosvita.mk.gov.ua/ua/1423729148/1539116610.

14. Nych T.V. Geography of the intellectual potential of the Khmelnitsky region / T.V. Nych. Kyiv: Print-Service, 2017 [In Ukrainian]. 
15. Oliynyk Y. B. Spatial Organization of Socio-geographical Processes in Ukraine / Ya. B. Oliynyk, L. M. Nemets, K. A. Nemets. - Kharkiv, 2003 [In Ukrainian].

16. Rating of schools of the Nikolaev area of 2019 [Electronic resource]. - Mode of access: https://osvita.ua/school/rating/65377.

17. Y. Oliinyk, T. Nych (2019) Educational complex of the Herson area: the current state and prospects of development. Visnyk Kyivskogo nacionalnogo universytetu imeni Tarasa Shevchenka, Geografiya [Bulletin of Taras Shevchenko National University of Kyiv, Geography], 1 (74), 23-29 (in Ukranian, abstr. in English).

Надійшла до редколегії 07.09.2020 